\title{
Recent Technological Advances in Thin Film Solar Cells
}

\author{
H.S. Ullal \\ K. Zwelbel \\ T. Surek
}

\section{March 1990}

Prepared for the World Renewable

Energy Congress

Reading, United KIngdom

23-28 September 1990

Prepared under Task No. PV040301

\author{
Solar Energy Research Institute \\ A Division of Midwest Research Institute \\ 1617 Cole Boulevard \\ Golden, Colorado 80401-3393 \\ Prepared for the \\ U.S. Department of Energy \\ Contract No. DE-AC02-83CH10093
}




\section{NOTICE}

This report was prepared as an account of work sponsored by an agency of the United States government. Neither the United States government nor any agency thereof, nor any of their employees, makes any warranty, express or implied, or assumes any legal liability or responsibility for the accuracy, completeness, or usefulness of any information, apparatus, product, or process disclosed, or represents that its use would not infringe privately owned rights. Reference herein to any specific commercial product, process, or service by trade name, trademark, manufacturer, or otherwise does not necessarily constitute or imply its endorsement, recommendation, or favoring by the United States government or any agency thereof. The views and opinions of authors expressed herein do not necessarily state or reflect those of the United States government or any agency thereof.

\section{Printed in the United States of America \\ Available from: \\ National Technical Information Service \\ U.S. Department of Commerce \\ 5285 Port Royal Road \\ Springfield, VA 22161}

\section{Price: Microfiche A01}

Printed Copy A02

Codes are used for pricing all publications. The code is determined by the number of pages in the publication. Information pertaining to the pricing codes can be found in the current issue of the following publications which are generally available in most libraries: Energy Research Abstracts (ERA); Government Reports Announcements and Index (GRA and I); Scientific and Technical Abstract Reports (STAR); and publication NTIS-PR-360 available from NTIS at the above address. 


\title{
RECENT TECHNOLOGICAL ADVANCES IN THIN FIIM SOLAR CEIUS
}

\author{
Harin S. Ullal, Kenneth Zweibel, and Thomas Surek @ \\ Solar Energy Research Instirute \\ 1617 Cole Boulevard \\ Golden, CO 80401, U.S.A.
}

\begin{abstract}
High-enficiency, low-cost thin film solar cells are an exciring photovoltaic technology option for generating cost-effective electricity in 1995 and beyond. This paper reviews the substancial advances made by several thin film solar cell technologies. namely, amorphous silicon, copper indium diselenide. cadmium telluride, and polycrystalline silicon. Recent examples of utility demonstracion projects of these emerging marerials are also discussed.
\end{abstract}

\section{KEYWORDS}

Amorphous silicon, cadmium telluride, copper indium diselenide, polycrystalline silicon, solar cells, thin-films, photovoltaic techology, photovoltaic systems

\section{DNIRODUCTION}

Thin film solar cells are an integral part of the photovoltaic (PV) technology base, whose main goals are to deliver electricity at $12 \Subset / \mathrm{kWh}$ in the year 1995 and $6 \mathrm{c} / \mathrm{kWh}$ by the year 2000 . To accomplish these major objectives, intense research and development is underway with the following marerials: amorphous silicon (a-Si), cadmium telluride (CdTe), copper indium diselenide (CulnSe, or CIS), and polycrystalline silicon (p-Si). Other solar cells such as crystalline silicon. sheet or ribbon silicon, gallium arsenide, and concentrator cells are also being investigated (Kazmersiki 1989). In this paper, we repor on the recent technological advances made by thin film solar cells in the past few years. Several advantages of thin-rilm solar cells have been reported elsewhere (Ullal et_al., 1989).

\section{AMORPHOUS SIIICON SOLAR CEUS AND TECHNOLOGY}

Ever since the first report of a-Si solar cell with a MUS strucrure was published by Carison and Wronski in 1976, there has been many groups that have actively pursued device fabrication. From 1982 to 1990 at least 27 groups woridwide have reported a cell efficiency of over 10\%. For small-area devices, Energy Conversion Devices has fabricated a multijunction cell with an active-area efficiency of $13.3 \%$, the highest efficiency a-Si device to date.

Much of the recent technological advances in a-Si have focused on module fabrication. The highest single-junction module efficiency for a-Si to date is $9.84 \%$ with a power output of 9.18 $W$ for an apermere area of $933 \mathrm{~cm}^{2}$ made by Solarex. The light I-V characteristic is shown in Fig. 1. Several advanced module design and processing steps have been incorporated, such as 
texured tin-oxide front contact. improved doping method for the p-layer, high-reflectivity back metallization. all laser-scribed patteming or modules, and a low-cost, spray-on encapsulant that has replaced the more expensive EVATTedlar package. ARCO Solar has fabricated a $9.4 \%$ efficient semi-uransparent square-foot module with a white back-reflector. Energy Conversion

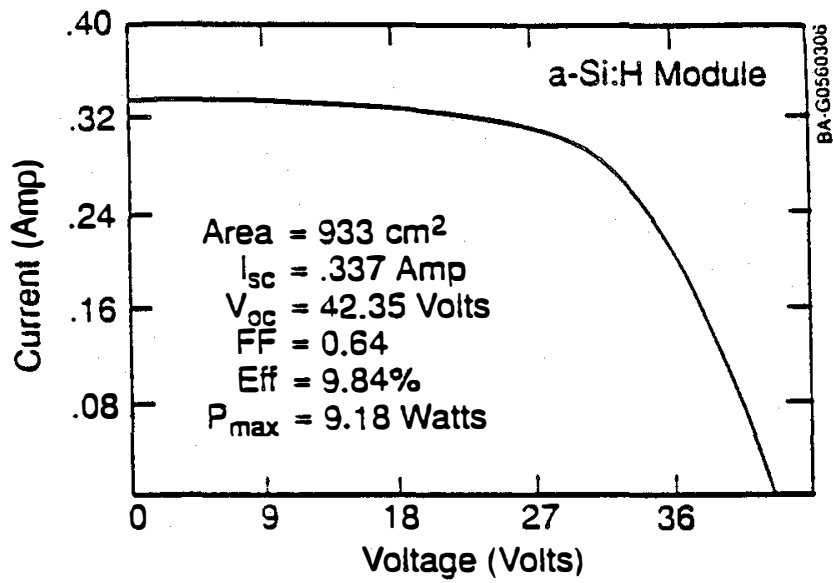

Fig. $1 \quad$ Light I - V characteristics of a $933 \mathrm{~cm}^{2}$ a-Si Solarex module

Devices has produced a $8.4 \%$ efficient multijunction square-foot module. The largest a-Si module ( $2.5 \mathrm{ft} \times 5 \mathrm{ft}$ ) has been fabricated by Chronar with a power output of about $62 \mathrm{~W}$ and an apernure area efficiency of $5.2 \%$. In the United States alone, there are at least seven companies. ARCO Solar, Chronar, Energy Conversion Devices, Glasstech Solar, Solarex, Utility Power Group and Iowa Thin Technologies that are actively involved in aking the a-Si technology from the lab to the market place. One of the key issues in this technology is the so-called "Staebler-Wronski" effect, i.e, a reduction in a-Si device efficiency upon exposure to light. To minimize this light-induced effects, two approaches are being pursued. The first is to use thin incrinsic layers of $0.2-0.3 \mu m_{0}$ while in the second case, the mulijunction device strucure represents an atractive engineering solution, with losses expected to be kept below 10\%. Research on multijunction on modules is currently underway, which potentially can result in cost-effective thin film a-Si modules.

\section{POLYCRYSTAWINE THIN FILMS}

Polycrystalline thin films (PIF) such as copper indium diselenide, cadmium telluride, and polycryscalline silicon have made substancial technical advances during the 1980s. Initially CIS. CdTe, and p-Si were competing for artencion along with copper sulfide, gallium arsenide, zinc phosphide and other polycrystalline thin films. Progress at Boeing in CIS, and at Kodak. Matsushita, Ametek, and Monosolar in CdTe led to polycrystalline thin films with efficiencies over 10\%. This key proof-of-concept aroused great interest in both CIS and CdTe. ARCO Solar and Intermational Solar Electric Technology (ISET) began work on CIS. Photon Energy and SOHIO/BP Solar started efforts in CdTe, and AstroPower in thin p-Si solar cells.

\section{Copper Indium Diselenide}

Following on the early CIS research at Boeing, ARCO Solar improved on the cell design by improving the blue response of the devices. In 1986. Choudary et al. proposed to replace the thick CdS layer which has a bandgap of $2.4 \mathrm{eV}$ with a "thin CdS" layer (<500 $\AA$ ) and a wide bandgap $\mathrm{ZnO}(3.2 \mathrm{eV})$ window layer. This improved the current density by about $6 \mathrm{~mA} / \mathrm{cm}^{2}$. or about 15\%. With this novel design shown in Fig. 2, ARCO Solar was able to repor achieving 14.1\% efficiency (active area. Mitchell et al. 1988). This latter efficiency was achieved with a CIS layer that included about $7 \% \mathrm{Ga}$ in place of In. The addition of $\mathrm{Ga}$ improves the open-circuit voltage of the CIS devices. Boeing has also done pioneering work in the area of $\mathrm{Ga}$ alloying and achieved $12.5 \%$ efficiency (total area) that has been verified at SERI. 


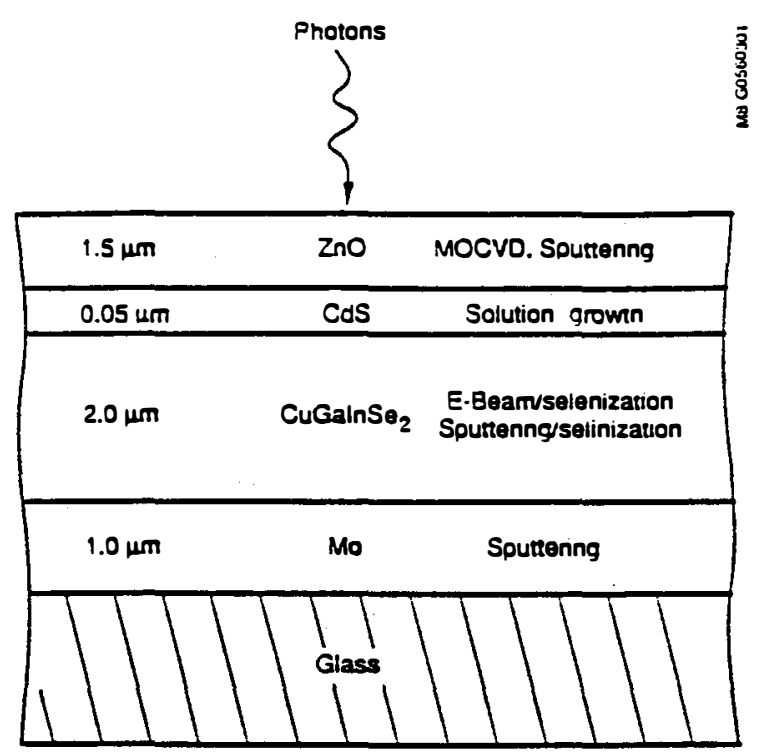

Fig. 2 Solar cell structure of a thin film CIS device

ARCO Solar has successfully scaled up their proprietary process for large-area CIS module fabrication. The sputtering/selenization method has been described in their patents (e.g., Love et al., 1984) and an European patent application (Eberspacher et al., 1988). In this approach, the deposition of $\mathrm{Cu}$ and In is sequential. The metais are about $2000 \AA$ of $\mathrm{Cu}$ and $4000 \AA$ of In and can be sputtered rapidly. ISET has demonstrared that the metals can also be deposited by E-beam evaporation Following this step, $\mathrm{Se}$ is introduced via $\mathrm{H}_{2} \mathrm{Se}$ gas and a carrier gas such as Ar or $\mathrm{N}_{2}$. Due to interdiffusion, the elements mix and form high quality CIS. ARCO Solar has demonstrated the effectiveness of their innovative device design and processing by making large-area modules. In 1988, they fabricated an $11.1 \%$ efficient CIS module with an aperme area of $938 \mathrm{~cm}^{2}$, and subsequently an even larger $9.1 \%$ efficient module with an aperare area of $3900 \mathrm{~cm}^{2}$ and a power output of $35.8 \mathrm{~W}$ before encapsularion was reported (Ermer et al., 1989). This large CIS module is presented in Fig. 3. Square-foot CIS modules have also been tested outdoors at SERI for over a year for their reliability, under both open-circuit and load conditions. No appreciable change in performance has been observed over this extended period of testing.

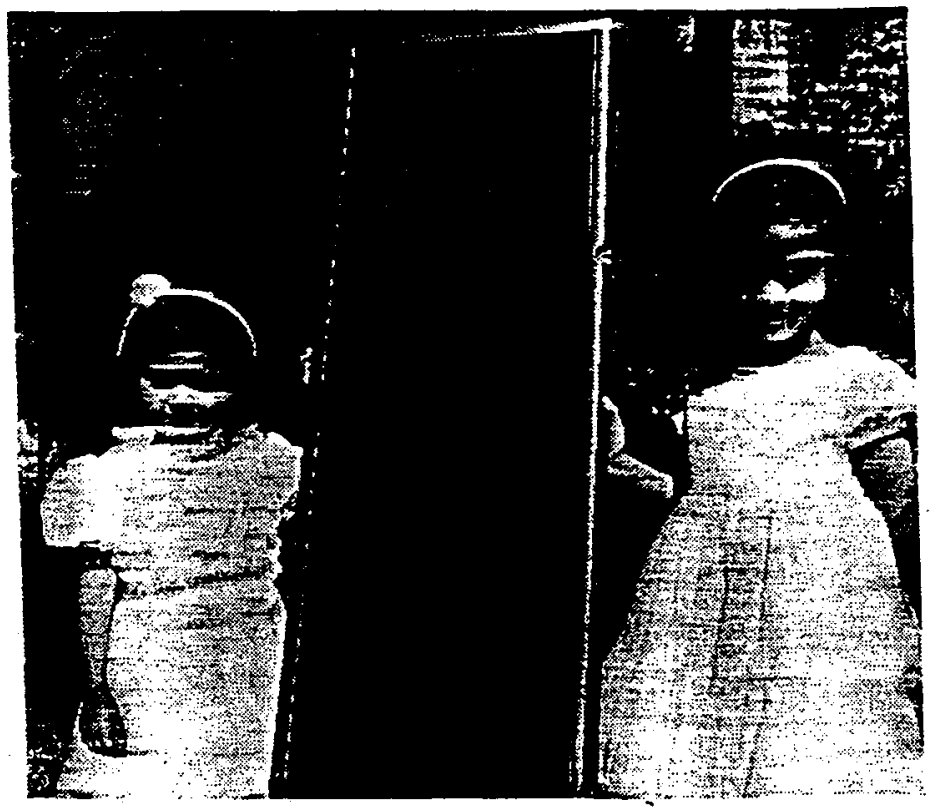

Fig. 3 A $3900 \mathrm{~cm}^{2}$ large-area CIS module fabricated by ARCO Solar with a power output of $35.8 \mathrm{~W}$ 


\section{Cadmium Telluride}

CdTe is another promising thin-film solar cell material. Its primary advantage is that it has the oprimum bandgap of $1.5 \mathrm{eV}$, which is well matched with the soiar spectrum. Although several methods are available to deposit thin-film CdTe (Ullal et al., 1989), the most promising ones are eletrodeposition and spraying. Photon Energy has successfully used the spray method to fabricate both high efficiency cells (12.3\%) and modules (7.3\%) (Albright et al., 1990). They have also fabricated four-square-foot prototype CdTe modules. Photon Energy has very aggressive neas-term goais to enter the PV production markets. Their cost estimates suggest that they may potentially be one of the lowest cost module manufacruress. They do not appear to require the same levels of manufacturing scale (i.e. $10 \mathrm{MW} /$ year) to achieve economies-of-scale. Infact they claim that they will achieve low cost (\$1-\$2/W modules) at a production level of about $3 \mathrm{MW} / \mathrm{year}$.

Another low-cost. non-vacuum method to deposit thin-film CdTe is electrodeposition. Both Ametek and BP Solar are pursuing this approach One of the main advantages of this method is the high materials unilizarion The key technology issue for CdTe devices is the conract stability. Ametek has circumvented this problem with a novel $n-i-p$ cell design. In this device strucare, the undoped CdTe is sandwiched between n-CdS and p-ZnTe. There is no direct metai contact to the high resistivity CdTe. Using this unique cell design, Ametek has fabricated 11.2\% efficient cells, while BP Solar has reported fabrication of $9 \%$ efficient $900 \mathrm{~cm}^{2}$ modules. Ametek has also tested their submodules for over 5000 hours, and within experimental error there are no significant changes in the submodule periormance. This is shown in Fig. 4.

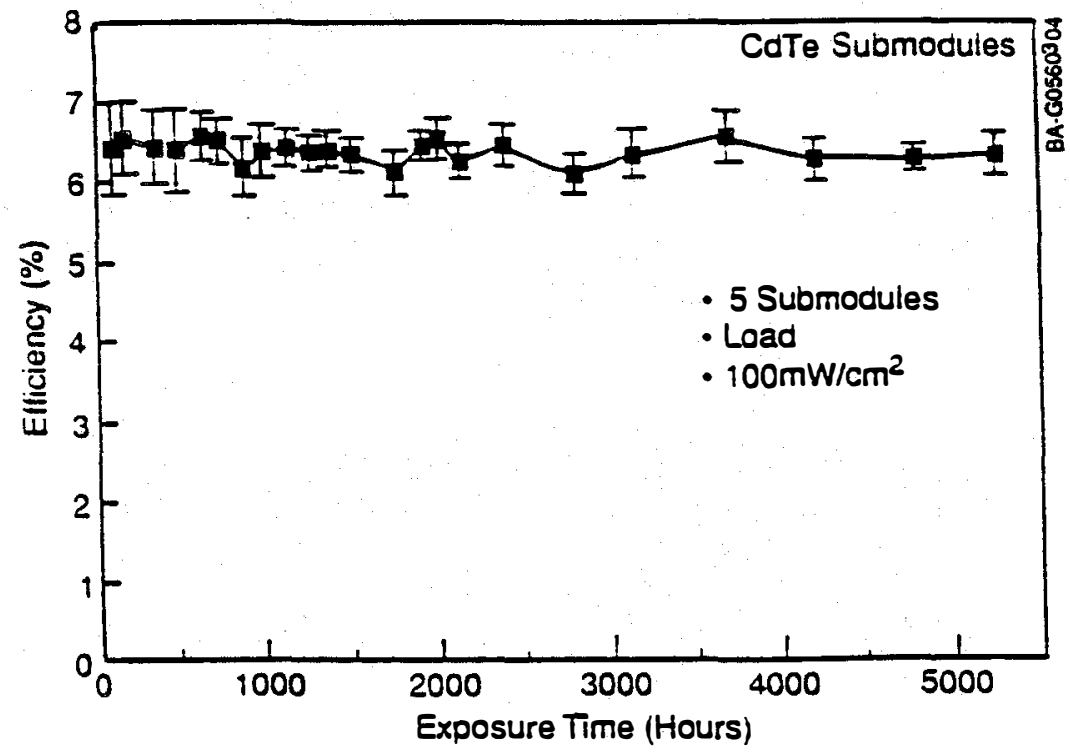

Fig. 4 Reporred stability performance of CdTe submodules tested indoors at Ametek

\section{Polyerystalline Silicon}

AstroPower is pursuing another awractive method for making low-cost thin-film solar cells. Their approach is to deposit silicon-films (thin p-Si) on a low-cost, ceramic substrate. Currearly the Si film thickness is about 80-100 $\mu \mathrm{m}$ and is projected to be reduced to 20-50 $\mu \mathrm{m}$ in the near fuare. This reduced thickness of the device along with an optical coupler for confining the incident photons via a light trapping mechanism will be used to enhance the performance of the cells. So far AstroPower has fabricared small-area laboratory devices with an efficiencies of $15.7 \%$ and commercial-size $\left(78 \mathrm{~cm}^{2}\right)$ devices of $8.5 \%$ (Bamett et al. 1989). 


\section{THIN FILM PV TECHNOLOGY DEMONSTRATION PROJECTS}

Due to the rapid progress made by thin film solar cell technologies there is an increasing interest on the par of utilities to test and evaluate the performance of these emerging technologies. The Photovoltaics for Utility Scale Applications (PVUSA) project - a joint project between a utiliy consorium and the U.S. Deparment of Energy has awarded contracts to thin film groups in a-Si, CIS, CdTe, and thin p-Si as part of their demonstration projects. System sizes varying from $20 \mathrm{~kW}$ to $400 \mathrm{~kW}$ will be installed in Davis, Califomia in mid to late 1990 to test these thin film PV systems.

\section{SUMMARY}

Thin film solar cells are strong candidates to generate cost-effective PV electricity of $12 \mathrm{c} / \mathrm{kWh}$ in the year 1995 and beyond. Several thin materials are being actively pursed to achieve this major objective: the most promising among them are: amorphous silicon, copper indium diselenide, cadmium telluride, and thin polycrystalline silicon Advanced module design and manufacruring methods are presently being investigated to lower the cost and develop stable large-area modules. This could potentially have a significant impact on global PV electricity production.

\section{Acknowledgment}

This work was supported by the U. S. Deparment of Energy under contract \# DE-ACO2$83 \mathrm{CH} 10093$.

\section{REFERENCES}

Albrighn, S.P., B. Ackerman, and J.F. Jordan (1990). Efficient CdTe/CdS solar cells and modules by spray processing. IEEE Trans. Electron Devices, 37 434-437

Bametr, A.M., F.A. Domian, D.H. Ford, C.L. Kendall, J.A. Rand, M.L. Rock and R.B. Hall (1989). Thin silicon-film solar cells on ceramic substrates. Proceedings of the 4th Intemarional Photovoltaic Science and Engineering Conference, Sydney, NSW Australia, February 14-17, 151-158

Eberspacher, C., J.R. Ermer and KW. Mitchell (1988). Process for making thin film solar cells. European Patent Applicarion No. 0318 315 A2. November 25

Ermer, J., C. Fredric, K Pauls, D. Pier, K. Mitchell, and C. Eberspacher (1989). Recent progress in large-area Cunse, submodules. Proceedings of the 4th Intermational Photovoltaic Science and Engineering Conference, Sydney, NSW Australia, February 14-17, 475-480

Kammerski. LL. (1989). Stams and assessment of photovoltaic technologies. Inter. Mats. Rev, 34, 185-210

Love, R.B. and U.V. Choudary (1984). Method for forming photovoltaic cells employing multinary semiconductor films. U.S. Patent No, 4.465.575. August 14

Mitchell. K., C. Eberspacher, J. Ermer, D. Pier (1988). Single and tandem junction CulnSe, cell and module technology. Proceedings of the 20th IEEE Photovoltaic Specialists Conference, Las Vegas, NV, September 26-30, 1384-1389

Ullal, HS. and K Zweibel (1989). Progress in thin film solar photovoltaic technologies. Proceedings of the 9th Miami Intemational Congress on Energy and Environmens, Miami Beach, FL, December 11-13, to be published 